(C) 2021 Universidad Nacional Autónoma de México, Facultad de Estudios Superiores Zaragoza.

This is an Open Access article under the CC BY-NC-ND license (http://creativecommons.org/licenses/by-nc-nd/4.0/).

TIP Revista Especializada en Ciencias Químico-Biológicas, 24: 1-8, 2021.

https://doi.org/10.22201/fesz.23958723e.2021.303

\title{
Chemical composition and phytotoxic potential of Eucalyptus globulus essential oil against Lactuca sativa and two herbicide-resistant weeds: Avena fatua and Amaranthus hybridus
}

\author{
Antonio Flores-Macías ${ }^{1}$, Guadalupe Georgina Reyes-Zarate ${ }^{1}$, \\ Claudio Augusto Gomes da Camara ${ }^{2}$, Reyes López-Ordaz ${ }^{1}$, \\ Juan Campos Guillén ${ }^{3}$ and Miguel Ángel Ramos-López ${ }^{3 *}$ \\ ${ }^{1}$ Department of Agricultural and Animal Production, Autonomous Metropolitan University Xochimilco \\ Unit, Calzada del Hueso \# 1100, Col.Villa Quietud, Alcaldía Xochimilco 04960 Mexico City, Mexico; \\ ${ }^{2}$ Department of Chemistry, Federal University of Pernambuco, Av. Dom Manoel de Medeiros, s / n \\ Recife, PE, Brazil; ${ }^{3}$ Faculty of Chemistry, Autonomous University of Querétaro, Cerro de las Campanas \\ s/n, Col. Las Campanas, Querétaro, 76010, Querétaro, Mexico. E-mail: *agromyke@yahoo.com
}

\begin{abstract}
Weed control in sustainable agriculture requires new bioherbicidal molecules to replace synthetic herbicides that have damaged the environment and generated resistance in weeds. This study was conducted to investigate the chemical composition of Eucalyptus globulus essential oil and to explore its bioherbicidal potential on the germination and radicle growth inhibition. The phytotoxic effects of $E$. globulus essential oil $\left(1,10\right.$ and $\left.20 \mu \mathrm{L} \mathrm{mL}^{-1}\right)$ were tested in comparison to those of the synthetic herbicide Glyphosate (1, 10 and $\left.20 \mu \mathrm{L} \mathrm{mL}^{-1}\right)$ in bioassays of germination and radicle growth of Lactuca sativa and the resistant weeds Avena fatua and Amaranthus hybridus. Gas Chromatography with Flame Ionization Detector and Gas Chromatography-Mass Spectroscopy analysis showed that major monoterpenes comprised 1,8-Cineole (86.94\%), $\alpha$-pinene $(7.71 \%)$, d-limonene $(2.65 \%)$, and p-cymene $(1.48 \%)$. The seed germination and radicle length exhibited different degrees of inhibition in response to the concentration of E. globulus essential oil. At some concentrations, both the Glyphosate herbicide and the E. globulus essential oil demonstrated the same phytotoxicity against the resistant weeds $A$. fatua and $A$. hybridus. Essential oil bioactivity Lethal Concentration $\left(\mathrm{LC}_{50}\right)$ in the majority of cases was lowest for A. hybridus, followed by A. fatua and L. sativa. Based on the results, it can be concluded that E. globulus essential oil possesses phytotoxic potential and could be explored as a bioherbicide for resistant weeds management programs.
\end{abstract}

Keywords: bioherbicide, allelochemicals; phytotoxicity; herbicide-resistant weeds.

Composición química y potencial fitotóxico de Eucalyptus globulus sobre Lactuca sativa y dos malezas resistentes a herbicidas: Avena fatua y Amaranthus hybridus

\begin{abstract}
RESUMEN
El control de las malezas en una agricultura sustentable requiere de nuevas moléculas bioherbicidas que sustituyan a los herbicidas sintéticos que han dañado al medio y generado resistencia en las malezas. El presente estudio, se realizó para determinar la composición química del aceite esencial de Eucalyptus globulus y explorar su potencial bioherbicida sobre la germinación y la inhibición del crecimiento radicular. Los efectos fitotóxicos del aceite esencial de E. globulus $\left(1,10\right.$ y $\left.20 \mu \mathrm{L} \mathrm{mL}^{-1}\right)$ se compararon con los ocasionados por el herbicida sintético Glifosato $\left(1,10\right.$ y $\left.20 \mu \mathrm{L} \mathrm{mL} \mathrm{m}^{-1}\right)$ mediante bioensayos de germinación y crecimiento de las raíces de Lactuca sativa y de las malezas resistentes a los herbicidas Avena fatua y Amaranthus hybridus. El análisis por Cromatografía de Gases con Detector de Ionización de Flama y Cromatografía de Gases-Espectrometría de Masas mostró que los monoterpenos principales fueron 1,8-cineol (86,94\%), $\alpha$-pineno (7,71\%), d-limoneno (2,65\%) y p-cimeno (1,48\%). La germinación de la semilla y la longitud de la radícula de ambas malezas exhibieron diferentes grados de inhibición en respuesta a la concentración del aceite esencial de E. globulus. En algunas concentraciones, tanto el herbicida Glifosato como el aceite esencial de E. globulus mostraron la misma fitotoxicidad contra las malezas estudiadas A. fatua y A. hybridus. La bioactividad de la Concentración Letal ( $\mathrm{LC}_{50}$, por sus siglas en inglés) del aceite esencial en la mayoría de los casos fue menor para $A$. hybridus, seguido de $A$. fatua y $L$. sativa. Con base en los resultados, se puede concluir que el aceite esencial de E. globulus posee potencial fitotóxico y podría ser explorado como un bioherbicida para programas de manejo de malezas resistentes.

Palabras clave: bioherbicida, aleloquímico, fitotóxico, malezas resistentes a herbicidas.
\end{abstract}

Artículo recibido el 22 de junio del 2020.

Artículo aceptado el 13 de marzo del 2021. 


\section{INTRODUCTION}

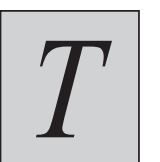

he overuse and misuse of huge amounts of synthetic herbicides for weed management has resulted in the emergence of herbicide-resistant weed biotypes and environmental contamination. The current worldwide demand for cheaper, more environmentally friendly weed management technologies has motivated a number of studies on allelochemicals or allelophatins as phytotoxic compounds to be used as bioherbicides (Dorota, Urszula, Renata \& Agnieszka, 2013; Rassaeifar, Hosseini, Haji, Zandi \& Moradi, 2013; Radhakrishnan, Alqarawi \& Abd_Allah, 2018). Allelochemicals are plant secondary metabolites and in the case of essential oils are synthesized during the isoprenoid pathway (Dorota et al., 2013). On the other hand, they are considered a potential source of novel molecules with herbicidal action for the chemical industry, the necessity of which is due to the emergence of weeds that are herbicide-resistant to synthetic molecules (Bhowmik \& Inderjit, 2003; Jabran, Mahajan, Sardana \& Chauhan, 2015). There are currently 467 unique cases of herbicide-resistant weeds globally, with 249 species and among them, the most resistant of these are Avena fatua, Amaranthus hybridus, Chenopodium album, Setaria viridis, Echinochloa crus-galli, Elusine indica, Kochia scoparia, and Conyza canadensis (Heap, 2018). Glyphosate has become the world's most widely used herbicide (Duke \& Powles, 2008), and new studies have been done on its effect on seed germination and radicle growth (Ismail, Chuah, Salmijah, Teng \& Schumacher, 2002; Yanniccari, Istilart, Giménez \& Castro, 2012; Gomes et al., 2017).

Mode of action of some allelochemicals is similar to synthetic herbicides. These features have allowed them to be considered for possible use in weed management as bioherbicides (Dorota et al., 2013). Phenolic acids and volatile oils released from the leaves, bark, and roots of certain Eucalyptus spp. have harmful effects on other plant species (Florentine \& Fox, 2003; Tang, Chen, Li \& Huang, 2014; Puig, Reigosa, Valentão, Andrade \& Pedrol, 2018). The phytotoxic effect of E. globulus essential oil against seed germination and seedling growth of some weeds has been demonstrated (Batish et al., 2007; Rassaeifar et al., 2013; Morsi \& Abdelmigid, 2016). E. globulus ssp. (blue gum) is one of the most widely planted eucalypts in temperate parts of the world (Barbour, Otahal, Vaillancourt \& Potts, 2008). Considering that allelochemicals of E. globulus could have potential use as bioherbicides, the main scope of this study was to characterize the chemical composition of eucalypt oil and to assess the phytotoxicity (on germination and radicle length) against one vegetable crop (L. sativa) and two herbicide-resistant weeds (A. fatua and A. hybridus) and compare it against herbicide Glyphosate, to provide insights into the suitability of this oil as a bioherbicide for weed management.

\section{Materials and METHOdS}

Seeds of $L$. sativa Great Lakes variety, $A$. fatua and $A$. hybridus were used in this experiment. E. globulus essential oil obtained by steam distillation was provided by a German trading company (PRIMAVERA ${ }^{\circledR}$ ).

\section{Quantification and Identification of essential oil main components \\ Gas Chromatography with Flame Ionization Detector (GC-FID)}

Quantitative GC analyses were carried out using a HewlettPackard 5890 Series II GC apparatus equipped with FID and a non-polar DB-5 fused silica capillary column (30 m x $0.25 \mathrm{~mm} \times 0.25 \mu \mathrm{m}$ film thickness) (J \& W Scientific). The oven temperature was programmed from 60 to $240{ }^{\circ} \mathrm{C}$ at a rate $3{ }^{\circ} \mathrm{C} \mathrm{min}^{-1}$ for integration purposes. Injector and detector temperatures were $260{ }^{\circ} \mathrm{C}$. Hydrogen was used as the carrier gas at a flow rate of $1 \mathrm{~L} \mathrm{~min}^{-1}$ and 30 p.s.i. inlet pressure in split mode (1:30). The injection volume was $0.5 \mu \mathrm{L}$ of diluted solution (0.01) of oil in n-hexane. The amount of each compound was calculated from GC peak areas in the order of DB-5 column elution and expressed as a relative percentage of the total area of the chromatograms. Analyses were carried out in triplicate.

Gas Chromatography-Mass Spectrometry Analysis (GC-MS) The GC-MS analysis was carried out using a Varian 220-MS IT GC system with a mass selective detector, mass spectrometer in EI $70 \mathrm{eV}$ with a scan interval of $0.5 \mathrm{~s}$ and fragments from 40 to $550 \mathrm{Da}$. fitted with the same column and temperature program as that for the GC experiments, with the following parameters: carrier gas $=$ helium; flow rate $=1 \mathrm{~mL} \mathrm{~min}^{-1}$; split mode (1:30); injected volume $=1 \mu \mathrm{L}$ of diluted solution $(0.01)$ of oil in n-hexane. Identification of the components was based on $\mathrm{GC}$ retention indices with reference to a homologous series of C8-C40 n-alkanes calculated using the Van den Dool and Kratz equation and by computer matching against the mass spectral library of the GC/MS data system (NIST 98 and WILEY) and co-injection with authentic standards as well as other published mass spectra. Area percentages were obtained electronically from the GC-FID response without the use of an internal standard or correction factors.

\section{Bioassay}

The bioassay consisted of the treatments: distilled water (negative control); Roundup ${ }^{\circledR}$ (Glyphosate isopropylamine salt) as positive control (at 1,10 and $20 \mu \mathrm{L} \mathrm{mL}^{-1}$ distilled water), essential oil (1, 10 and $\left.20 \mu \mathrm{L} \mathrm{mL}^{-1}\right)$ and distilled water + Tween $^{\circledR} 20$ (polyoxyethylene [20] sorbitan monolaurate), at $5 \%(\mathrm{v} / \mathrm{v})$. Treatments were distributed in a completely randomized design with 30 replicates each. The synthetic herbicide Roundup ${ }^{\circledR}$ is recommended to apply at 2 - $4 \mathrm{~L} \mathrm{ha}^{-1}$ $\left(10-20 \mu \mathrm{L} \mathrm{mL}^{-1}\right)$. 
E. globulus essential oil effects were evaluated on germination and radicle length in the previously mentioned species. The experiment was repeated during two periods.

One seed of each species was placed onto non-toxic paper (Whatman No. 1 filter paper) about $4 \mathrm{~cm}$ from the top edge, leaving a $3-4 \mathrm{~cm}$ gap on the sides; each seed was then covered with a second sheet of moist paper. The sheet of paper was rolled and placed upright in a deep-bottomed test tube, and $5 \mathrm{~mL}$ of each treatment to be evaluated was added (Gold, 2009). The test tubes were sealed with a paraffin film and placed in a growth chamber set at $22{ }^{\circ} \mathrm{C} \pm 1{ }^{\circ} \mathrm{C}, 50 \% \pm$ $1 \% \mathrm{RH}$, for $16: 8 \mathrm{~h}$ light/dark cycles. After 7 days, the number of germinated seeds and radicle lengths were measured by unrolling the paper carefully to avoid tearing it or damaging the radicles of the young seedlings. Mortality was calculated based on seeds not germinated. The percentage of Radicle Growth Inhibition (RGI) was calculated by the difference between growth of Treatments $(\mathrm{T})$ and the negative Control (C) using the following equation:

$$
\mathrm{RGI}=(\mathrm{C}-\mathrm{T}) / \mathrm{C}) \times 100
$$

\section{Statistical data analysis}

All measured variables were tested for normality (ShapiroWilk W test) and homoscedasticity (Bartlett test). KruskalWallis non-parametric analysis of variance was utilized when data violated the normality assumption and could not be corrected employing a transformation. One-way analysis of variance (ANOVA) and Tukey test $(p<0.05)$ were also performed to detect possible differences among the treatments. Linear regression analysis was used for quantifying the relationship between the essential oil concentration and seed germination and radicle length of the three species studied. The 50\% Lethal Concentration $\left(\mathrm{LC}_{50}\right)$ (concentration causing $50 \%$ mortality compared to the control) was calculated for each treatment by probit analysis, based on mortality (seeds not germinated) obtained at each concentration of the samples (SAS, 2012).

\section{RESULTS AND DISCUSSION}

\section{Essential oil main components}

GC-FID and GC-MS analysis demonstrated that the oil is mainly a mixture of monoterpenes, sesquiterpenes and alcohols. Dominant among the constituents were the monoterpenes, constituting approximately $97.41 \%$ of the oil (Table I). Major monoterpenes included the oxygenated monoterpene 1,8-cineole (77.91\%), p-cymene (10.19\%) and the monoterpene hydrocarbon $\alpha$-pinene $(4.33 \%)$.

Previous studies have found that major constituents of Eucalyptus spp. essential oils are 1,8-cineole (49.07 to $83.59 \%$ ) and $\alpha$-pinene (1.27-26.35\%) (Zhang, An, Wu, Liu \& Stanton, 2012; Sebei, Sakouhi, Herchi, Khouja \& Boukhchina, 2015; Morsi \& Abdelmigid, 2016). 1,8-cineole is the most important compound of the genus Eucalyptus and is largely responsible for a variety of its pesticidal properties (Batish, Singh, Kohli \& Kaur, 2008) and its antibacterial activity against Gram-positive and Gram- bacteria, related with the presence of this oxygenated compound (Ben et al., 2011). Different composition may be due to genetic variability between species of E. globulus, environmental factors and extraction procedures.

Table I. Essential oil main components of Eucalyptus globulus and optical rotation.

\begin{tabular}{|l|c|c|c|c|}
\hline \multicolumn{1}{|c|}{ Compound } & $\mathbf{R I}^{\mathbf{a}}$ & $\mathbf{L R}^{\mathbf{b}}$ & $\mathbf{\%}$ & Method of identification \\
\hline$\alpha$-thujene & 924 & 923 & $0,15 \pm 0,00$ & RI, MS \\
\hline$\alpha$-pinene & 932 & 930 & $4,33 \pm 0,09$ & RI, MS,CI \\
\hline sabinene & 969 & 970 & $0,52 \pm 0,00$ & RI, MS \\
\hline$\beta$-pinene & 975 & 976 & $1,97 \pm 0,03$ & RI, MS, CI \\
\hline myrcene & 988 & 989 & $0,62 \pm 0,04$ & RI, MS \\
\hline$\alpha$-phellandrene & 1002 & 1003 & $0,18 \pm 0,00$ & RI, MS \\
\hline p-cymene & 1020 & 1021 & $10,19 \pm 0,37$ & RI, MS, CI \\
\hline 1,8 -cineole & 1026 & 1025 & $77,91 \pm 1,14$ & RI, MS, CI \\
\hline$Z$ - $\beta$-ocimene & 1032 & 1034 & $0,72 \pm 0,01$ & RI, MS \\
\hline$\gamma$-terpinolene & 1054 & 1055 & $0,17 \pm 0,00$ & RI, MS \\
\hline terpinolene & 1086 & 1089 & $0,65 \pm 0,00$ & RI, MS, CI \\
\hline Total & & & $97,41 \pm 1,09$ & \\
\hline
\end{tabular}

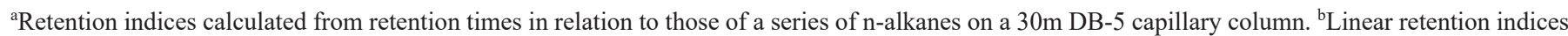
from the literature $\mathrm{RI}=$ retention index, $\mathrm{MS}=$ mass spectrum, $\mathrm{CI}=$ co-injection with authentic standards. 


\section{Data analyzed by germination}

ANOVA values indicated that differences between treatments and between species were significant $(p<0.01)$ and species $\times$ treatments $(p<0.01)$. There was not a significant difference for each species between the treatments comprising distilled water + Tween ${ }^{\circledR}$ and distilled water.

L. sativa exhibited the highest number of seeds germinated in all treatments. With regard to A. fatua and A. hybridus, Glyphosate treatment at $20 \mu \mathrm{L} \mathrm{mL}-1$ completely inhibited germination (Table II).

Essential oil treatments showed the highest average of germination in L. sativa, which has a middle-sized seed compared with A. fatua and A. hybridus. Batish et al. (2008) concluded that eucalyptus oil exhibits species-specific toxicity and that the toxic effect was more noticeable in small-seeded crops such as Amaranthus viridis compared with large-seeded Raphanus sativus. Treatment with essential oil at concentrations of 10 and $20 \mu \mathrm{L} \mathrm{mL}^{-1}$ caused greatest inhibition $(p<0.01)$ of germination in $A$. hybridus, overcoming the inhibitory effect achieved in the species L. sativa and A. fatua (Table II). This indicates that $A$. hybridus is more sensitive to be inhibited in its germination by the essential oil in comparison with the other two species studied. This shows that $A$. hybridus is a species in which the phytotoxicity caused by the E. globulus essential oil occurs at low doses. Regarding the E. globulus essential oil $\mathrm{LC}_{50}$, the lowest concentration was $A$. hybridus $\left(<1 \mu \mathrm{L} \mathrm{mL} \mathrm{m}^{-1}\right)$, followed by the dose for A. fatua $\left(11.78 \mu \mathrm{L} \mathrm{mL}^{-1}\right)$ and L. sativa $(>20 \mu \mathrm{L} \mathrm{mL}-1)$.

Inhibition of germination caused by E. globulus essential oils and Glyphosate treatments on three seeds were highest for $A$. hybridus, followed by A. fatua and then by L. sativa. However, the inhibition of germination caused by Glyphosate was higher than the effect of essential oil on all concentrations. Batish, Setia, Singh \& Kohli (2004) found that E. globulus essential oils caused inhibition in the germination and radicle growth of A. viridis, Cassia occidentalis, E. crus-galli, R. sativus, Triticum aestivum and Zea mays. This result suggests that E. globulus essential oils could possess a greater capacity to severely affect the germination, although the different plants species involved prevent direct comparisons. This could be related with volatile monoterpenes, eucalyptol (1,8-cineole), and camphor, which can induce nuclear abnormalities and increasing vacuole numbers (Nishida, Tamotsu, Nagata, Saito \& Sakai, 2005; Pawlowski, Kaltchuk-Santos, Zini, Caramao \& Soares, 2012). Batish et al. (2007) speculated that eucalypt oil inhibits the mitotic activity of growing cells; however, the mechanism of the inhibitory effect remains unknown. On the other hand, $\alpha$-pinene, the third major component of E. globulus essential oil acts under at least two mechanisms: uncoupling of oxidative phosphorylation, and inhibition of
Table II. Effect of Eucalyptus globulus essential oil and Glyphosate herbicide on average germination of Avena fatua, Amaranthus hybridus and Lactuca sativa.

\begin{tabular}{|c|c|c|}
\hline Treatment & Species & Average germination \\
\hline Distilled water & $\begin{array}{l}\text { L. sativa } \\
\text { A. fatua } \\
\text { A. hybridus }\end{array}$ & $\begin{array}{l}1.000 \pm 0.00 \mathrm{a} \\
0.633 \pm 0.08 \mathrm{efgh} \\
0.867 \pm 0.06 \mathrm{abcd}\end{array}$ \\
\hline \multicolumn{3}{|l|}{ E. globulus } \\
\hline $1 \mu \mathrm{L} \mathrm{mL}^{-1}$ & $\begin{array}{l}\text { L. sativa } \\
\text { A. fatua } \\
\text { A. hybridus }\end{array}$ & $\begin{array}{l}0.933 \pm 0.04 \mathrm{ab} \\
0.733 \pm 0.08 \mathrm{cdefg} \\
0.433 \pm 0.09 \mathrm{i}\end{array}$ \\
\hline $10 \mu \mathrm{L} \mathrm{mL}^{-1}$ & $\begin{array}{l}\text { L. sativa } \\
\text { A. fatua } \\
\text { A. hybridus }\end{array}$ & $\begin{array}{l}0.800 \pm 0.07 \mathrm{bcde} \\
0.533 \pm 0.09 \mathrm{hi} \\
0.233 \pm 0.07 \mathrm{j}\end{array}$ \\
\hline $20 \mu \mathrm{L} \mathrm{mL}^{-1}$ & $\begin{array}{l}\text { L. sativa } \\
\text { A. fatua } \\
\text { A. hybridus }\end{array}$ & $\begin{array}{l}0.633 \pm 0.08 \text { efgh } \\
0.433 \pm 0.09 \mathrm{i} \\
0.200 \pm 0.07 \mathrm{jk}\end{array}$ \\
\hline \multicolumn{3}{|l|}{ Glyphosate } \\
\hline $1 \mu \mathrm{L} \mathrm{mL}^{-1}$ & $\begin{array}{l}\text { L. sativa } \\
\text { A. fatua } \\
\text { A. hybridus }\end{array}$ & $\begin{array}{l}0.600 \pm 0.09 \text { fghi } \\
0.567 \pm 0.07 \text { ghi } \\
0.033 \pm 0.03 \mathrm{kl}\end{array}$ \\
\hline $10 \mu \mathrm{L} \mathrm{mL}^{-1}$ & $\begin{array}{l}\text { L. sativa } \\
\text { A. fatua } \\
\text { A. hybridus }\end{array}$ & $\begin{array}{l}0.767 \pm 0.07 \mathrm{bcdef} \\
0.200 \pm 0.07 \mathrm{jk} \\
0.000 \pm 0.071\end{array}$ \\
\hline $20 \mu \mathrm{L} \mathrm{mL}^{-1}$ & $\begin{array}{l}\text { L. sativa } \\
\text { A. fatua } \\
\text { A. hybridus }\end{array}$ & $\begin{array}{l}0.167 \pm 0.06 \mathrm{jkl} \\
0.000 \pm 0.071 \\
0.000 \pm 0.001\end{array}$ \\
\hline $\begin{array}{l}\text { Distilled water } \\
\text { +Tween } 囚 20\end{array}$ & $\begin{array}{l}\text { L. sativa } \\
\text { A. fatua } \\
\text { A. hybridus }\end{array}$ & $\begin{array}{l}1.000 \pm 0.00 \mathrm{a} \\
0.700 \pm 0.08 \mathrm{defch} \\
0.900 \pm 0.05 \mathrm{abc}\end{array}$ \\
\hline
\end{tabular}

The values refer to means \pm S.E. For a given measurement, mean values with the same letter in the same column are not significantly different $(p<0.05$ Tukey test $)$.

electron transfer (Nishida et al., 2005) and allelochemicals might inhibit seed germination by suppressing the synthesis of gibberellins and indole acetic acid (Chu et al., 2014).

A partial correlation analysis between seed germination and oil concentration (positive correlation) suggested that the phytotoxicity effects of the essential oil of E. globulus might cause inhibition of seed germination.

\section{Data analyzed by radicle length}

The three species demonstrated highest radicle growth $(p<0.05)$ in treatments with distilled water and distilled water + Tween $^{\circledR}$, probably showing that division and/or the cell growth level radicle were normal (Table III).

When comparing the effect of radicle growth among the three species evaluated, the species $A$. fatua exhibited highest 
Table III. Effect of Eucalyptus globulus oil and Glyphosate herbicide on average radicle length and percentage of Radicle Growth Inhibition (RGI) of Avena fatua, Amaranthus hybridus and Lactuca sativa.

\begin{tabular}{|c|c|c|c|}
\hline Treatment & Species & $\begin{array}{l}\text { Average radicle } \\
\text { length }(\mathrm{mm})\end{array}$ & $\begin{array}{l}\text { RGI } \\
(\%)\end{array}$ \\
\hline \multicolumn{4}{|c|}{ Distilled water } \\
\hline & $\begin{array}{l}\text { L. sativa } \\
\text { A. fatua } \\
\text { A. hybridus }\end{array}$ & $\begin{array}{l}3.000 \pm 0.14 \mathrm{~d} \\
8.671 \pm 0.30 \mathrm{~b} \\
2.436 \pm 0.19 \mathrm{ef}\end{array}$ & $\begin{array}{l}0 \\
0 \\
0\end{array}$ \\
\hline \multicolumn{4}{|l|}{ E. globulus } \\
\hline $1 \mu \mathrm{L} \mathrm{mL}^{-1}$ & $\begin{array}{l}\text { L. sativa } \\
\text { A. fatua } \\
\text { A. hybridus }\end{array}$ & $\begin{array}{l}0.500 \pm 0.08 \mathrm{~g} \\
0.425 \pm 0.04 \mathrm{~h} \\
0.177 \pm 0.04 \mathrm{~h}\end{array}$ & $\begin{array}{l}85.3 \\
95.1 \\
92.7\end{array}$ \\
\hline $10 \mu \mathrm{L} \mathrm{mL}^{-1}$ & $\begin{array}{l}\text { L. sativa } \\
\text { A. fatua } \\
\text { A. hybridus }\end{array}$ & $\begin{array}{l}0.284 \pm 0.02 \mathrm{~h} \\
0.189 \pm 0.03 \mathrm{~h} \\
0.157 \pm 0.02 \mathrm{~h}\end{array}$ & $\begin{array}{l}90.5 \\
97.8 \\
93.6\end{array}$ \\
\hline $20 \mu \mathrm{L} \mathrm{mL}^{-1}$ & $\begin{array}{l}\text { L. sativa } \\
\text { A. fatua } \\
\text { A. hybridus }\end{array}$ & $\begin{array}{l}0.177 \pm 0.02 \mathrm{~h} \\
0.047 \pm 0.02 \mathrm{~h} \\
0.233 \pm 0.03 \mathrm{~h}\end{array}$ & $\begin{array}{l}94.1 \\
99.5 \\
90.4\end{array}$ \\
\hline \multicolumn{4}{|l|}{ Glyphosate } \\
\hline $1 \mu \mathrm{L} \mathrm{mL}^{-1}$ & $\begin{array}{l}\text { L. sativa } \\
\text { A. fatua } \\
\text { A. hybridus }\end{array}$ & $\begin{array}{l}1.313 \pm 0.12 \mathrm{f} \\
3.920 \pm 0.65 \mathrm{c} \\
0.200 \pm 0.00 \mathrm{~h}\end{array}$ & $\begin{array}{l}56.2 \\
54.8 \\
91.8\end{array}$ \\
\hline $10 \mu \mathrm{L} \mathrm{mL}^{-1}$ & $\begin{array}{l}\text { L. sativa } \\
\text { A. fatua } \\
\text { A. hybridus }\end{array}$ & $\begin{array}{l}2.304 \pm 0.27 \mathrm{f} \\
0.267 \pm 0.12 \mathrm{~h} \\
0.000 \pm 0.00 \mathrm{i}\end{array}$ & $\begin{array}{c}23.2 \\
96.9 \\
100.0\end{array}$ \\
\hline $20 \mu \mathrm{L} \mathrm{mL}^{-1}$ & $\begin{array}{l}\text { L. sativa } \\
\text { A. fatua } \\
\text { A. hybridus }\end{array}$ & $\begin{array}{c}0.290 \pm 0.06 \mathrm{~h} \\
0.000 \pm 0.00 \mathrm{i} \\
0.000 \pm 0.00 \mathrm{i}\end{array}$ & $\begin{array}{l}90.3 \\
100.0 \\
100.0\end{array}$ \\
\hline \multicolumn{4}{|c|}{ Distilled water + Tween ${ }^{\circledR}$} \\
\hline & $\begin{array}{l}\text { L. sativa } \\
\text { A. fatua } \\
\text { A. hybridus }\end{array}$ & $\begin{array}{c}3.101 \pm 1.4 \mathrm{~d} \\
9.861 \pm 0.41 \mathrm{a} \\
2.501 \pm 0.18 \mathrm{e}\end{array}$ & $\begin{array}{l}- \\
- \\
-\end{array}$ \\
\hline
\end{tabular}

The values refer to means \pm S.E. For a given measurement, mean values with the same letter in the same column are not significantly different ( $p<0.05$ Tukey test).

growth $(p<0.05)$ in distilled water + Tween $^{\circledR}$, followed by the treatment with water $(p<0.01)$. L. sativa had highest radicle lenght at the $1 \mu \mathrm{L} \mathrm{mL} \mathrm{m}^{-1}$ concentration of the essential oil compared with the other two species. No difference was observed in radicle growth and RGI among two other species at 10 and $20 \mu \mathrm{L} \mathrm{mL}^{-1}$ concentrations of the essential oil. The RGI caused by the essential oil concentrations of 10 and $20 \mu \mathrm{L} \mathrm{mL}^{-1}$ was statistically equal $(p<0.05)$ to that achieved by the Glyphosate concentration at $10 \mu \mathrm{L} \mathrm{mL} \mathrm{m}^{-1}$ on A. fatua and $1 \mu \mathrm{L} \mathrm{mL}-1$ on A. hybridus and $20 \mu \mathrm{L} \mathrm{mL}^{-1}$ on L. sativa. The phytotoxic effect of the essential oil is equal to that of Glyphosate, although at higher concentrations, shows that it has the potential to cause effects similar to those of the synthetic herbicide, but most likely without its adverse effects on the environment. A. fatua showed significantly higher radicle lenght $(p<0.05)$ at $1 \mu \mathrm{L} \mathrm{mL}^{-1}$ concentration of Glyphosate compared with other seeds treated with different concentrations of Glyphosate and essential oil. This suggests that $A$. fatua resists the toxic effect of Glyphosate at its lowest concentration, exhibiting some type of resistance. This species has been reported as a herbicide-resistant weed (Heap, 2018). The increase in the concentration of E. globulus essential oil did not cause a significant increase in RGI. However, Rassaeifar et al. (2013), in working with E. globulus essential oil on seedling establishment of Amaranthus blitoides and Cynodon dactylon, found that when the concentration of the essential oil increases $(0.00005$ to $0.005 \mu \mathrm{L} \mathrm{mL}-1)$, radicle length decreases.

\section{Data analyzed by species Avena fatua}

In $A$. fatua germination, there was no significant difference between the essential oil in increasing concentrations $(10 \mu \mathrm{L}$ and $20 \mu \mathrm{L} \mathrm{mL}^{-1}$ ), and Glyphosate at its lowest concentration (1 $\left.\mu \mathrm{L} \mathrm{mL} \mathrm{mL}^{-1}\right)$. This indicated that the essential oil showed a phytotoxic effect equal to that of the Glyphosate. However, an increase in the concentration of the essential oil does not decrease the germination in A. fatua. Rassaeifar et al. (2013) showed that the germination percentage and germination rate of $A$. blitoides and $C$. dactylon decreased by increasing the concentration of E. globulus essential oil. On the other hand, El-Rokiek \& Eid (2009) demonstrated that the germination percentage of wild oat seeds was negatively affected by the fresh and dry leaf extract of Eucalyptus citriodora at different concentrations.

Regression analysis of average radicle length exhibited a positive linear correlation with increasing concentrations of E. globulus essential oil $\left(R^{2}=0.97 ; p<0.05\right)$ where the RGI was $95.1 \%$ at $1 \mu \mathrm{L} \mathrm{mL}^{-1}$ and increased to $99.5 \%$ at the highest concentration $\left(20 \mu \mathrm{L} \mathrm{mL} \mathrm{m}^{-1}\right)$. Similar results were found by Vishwakarma \& Mittal (2014), who demonstrated that root development was $24 \%$ in high concentrations and reached $84 \%$ in low concentrations. The essential oil of E. globulus at three concentrations and Glyphosate $\left(10 \mathrm{~mL}^{-1}\right)$ showed an equal capacity to inhibit root growth in $A$. fatua. These results indicated that the essential oil did not show strong inhibition of germination; however, its main effect was on the inhibition of radicle growth. This allows to suppose that the use of E. globulus essential oil can delay the growth and development of this weed and potentially reduce the negative effects resulting from the use of Glyphosate. The use of E. globulus essential oils instead of synthetic herbicides could have a lower ecological impact, lower selection pressure, and reduce health and environmental problems. 


\section{Amaranthus hybridus}

Regression analysis showed that germination of $A$. hybridus had a positive linear correlation with increasing concentrations of essential oil $\left(R^{2}=0.83 ; p<0.05\right)$. Likewise, previous investigation has shown that the essential oil of eucalyptus species increases the inhibition of germination by increasing the concentration of the essential oil (Rassaeifar et al., 2013; Vishwakarma \& Mittal, 2014).

Treatments with essential oil demonstrated significantly greater inhibition $(p \leq 0.05)$ on germination and radicle growth when compared with control (Table II and III). At the highest concentration of the essential oil $\left(20 \mu \mathrm{L} \mathrm{mL}^{-1}\right)$, the inhibition on germination was statistically the same as that caused by Glyphosate at ( 1 and $\left.10 \mu \mathrm{L} \mathrm{mL}^{-1}\right)$. Once again, we can suppose that the use of the essential oil of E. globulus instead of the synthetic herbicide Glyphosate could have similar phytotoxic effects but less negative consequences on the environment. Increasing concentrations of the essential oil inhibited germination in a different manner, but not radicle growth. Batish et al. (2007), studying the effect of the essential oil of E. citriodora on Phalaris minor, found that this caused a greater effect on seedling growth than on germination. Based on this, studying the effect of foliar application of essential oil of E. globulus on herbicide resistant species is a topic that could be analyzed in future research. In the present study, the magnitude of the phytotoxic effect was observed both in radicle growth and germination. The essential oil at its three concentrations possesses the same radicle growth inhibitory effect as Glyphosate at its lowest concentration (RGI, 90.4 and 91.8 , respectively).

\section{Lactuca sativa}

In the species $L$. sativa, treatments showed significantly higher germination $(p \leq 0.01)$ in distilled water and distilled water + Tween $^{\circledR}$ and essential oil at its lowest concentration ( $1 \mu \mathrm{L} \mathrm{mL} \mathrm{m}^{-1}$ ) compared with the other treatments.

Glyphosate demonstrated highest inhibition of germination at $20 \mu \mathrm{L} \mathrm{mL}-1$. Treatments with essential oil at the three concentrations $\left(1,10\right.$, and $\left.20 \mu \mathrm{L} \mathrm{mL}^{-1}\right)$ exhibited inhibition on germination that was statistically equal to that of Glyphosate at $10 \mu \mathrm{L} \mathrm{mL}-1$; the essential oil at such concentrations is as effective in inhibiting germination as Glyphosate (Table II). Yamagushi, Gusman \& Vestena (2011) and de Souza \& Cardoso (2013) found that aqueous extracts of E. globulus at increasing concentrations $\left(100,000-1,000,000 \mu \mathrm{L} \mathrm{mL} \mathrm{mL}^{-1}\right)$ occasioned the increase of inhibition of germination and of RGI of L. sativa. However, in the present study the concentrations were lower, and RGI was statistically equal at increasing concentrations.

Treatments with the essential oil (10 and $20 \mu \mathrm{L} \mathrm{mL}-1)$ showed RGI that was statistically equal to that of Glyphosate at $20 \mu \mathrm{L} \mathrm{mL} \mathrm{m}^{-1}$ and significantly higher than the controls (distilled water and distilled water + Tween ${ }^{\circledR}$ ). On increasing the concentration of essential oil, inhibition of germination is increased. However, the RGI is statistically equal and is not affected by the increase in oil concentration from 10 to $20 \mu \mathrm{L} \mathrm{mL} \mathrm{m}^{-1}$. Apparently, the emerged radicle of L. sativa exhibited Glyphosate resistance at its concentrations 1 and $10 \mu \mathrm{L} \mathrm{mL}^{-1}$.

\section{Conclusions}

The major compounds of the E. globulus essential oil were monoterpenes 1,8-cineole (77.91\%) and p-cymene $(10,19 \%)$. Correlation analysis suggested that inhibition of seed germination and radicle growth might be caused by a phytotoxic potential of E. globulus essential oil. The latter showed differential bioactivity between the different plant species; being $\mathrm{LC}_{50}$ lowest for $A$. hybridus, followed by $A$. fatua and L. sativa.

The higher inhibition of root growth caused by essential oil compared to Glyphosate (at $1 \mu \mathrm{L} \mathrm{mL}^{-1}$ ) can be used as a strategy to gradually affect the development of $A$. fatua, with a lower ecological cost. The higher the concentration of essential oil of E. globulus, the greater the inhibition of germination and the percentage of inhibition of radicle growth. At some of the evaluated concentrations, both the Glyphosate herbicide and the E. globulus essential oil demonstrated the same phytotoxicity against the resistant weeds $A$. fatua and A. hybridus.

E. globulus essential oil may be considered a potential source of new molecules with herbicidal action for the chemical industry and could be incorporated as a bioherbicide into agriculture. However, there is a need for the study of long-term crop-weed phytotoxic interactions under field conditions.

\section{ACKNOWLeDgMent}

The authors gratefully acknowledge National Science and Technology Council of Mexico (CONACYT) funds for this Scientific Research.

\section{REFERENCES}

Barbour, R. C., Otahal, Y., Vaillancourt, R. E. \& Potts, B. M. (2008). Assessing the risk of pollen-mediated gene flow from exotic Eucalyptus globulus plantations into native eucalypt populations of Australia. Biological Conservation, 141, 896-907. https://doi.org/10.1016/j. biocon.2007.12.016

Batish, D. R., Setia, N., Singh, H. P. \& Kohli, R. K. (2004). Phytotoxicity of lemon-scented eucalypt oil and its potential use as a bioherbicide. Crop Protection, 23, 1209-1214. https://doi.org/10.1016/j.cropro.2004.05.009

Batish, D. R., Singh, H. P., Setia, N., Kohli, R. K., Kaur, S. \& Yadav, S. S. (2007). Alternative control of littleseed 
canary grass using eucalypt oil. Agronomy for Sustainable Development, 27(3), 171-177 https://doi.org/10.1051/ agro:2007008

Batish, D. R, Singh, H. P., Kohli, R. K. \& Kaur, S. (2008). Eucalyptus essential oil as a natural pesticide. Forest Ecology and Management, 256(12), 2166-2174, https:// doi.org/10.1016/j.foreco.2008.08.008

Ben, M. H. N., Romdhane, M., Lebrihi, A., Mathieu, F., Couderc, F., Abderraba, M. \& Bouajila, J. (2011). Eucalyptus oleosa essential oils: chemical composition and antimicrobial and antioxidant activities of the oils from different plant parts (stems, leaves, flowers and fruits). Molecules, (Basel, Switzerland), 16(2), 16951709 https://doi.org/10.3390/molecules 16021695

Bhowmik, P. C. \& Inderjit, S. (2003). Challenges and opportunities in implementing allelopathy for natural weed management. Crop Protection, 22(4), 661-671 https://doi.org/10.1016/s0261-2194(02)00242-9

Chu, C., Mortimer, P. E., Wang, H., Wang, Y., Liu, X. \& Yu, S. (2014). Allelopathic effects of eucalyptus on native and introduced tree species. Forest Ecology and Management, 323, 79-84. https://doi.org/10.1016/j. foreco.2014.03.004

de Souza, M. \& Cardoso, S. B. (2013). Efeito alelopático do extrato de folhas de Eucalyptus grandis sobre a germinação de Lactuca sativa L. (ALFACE) e Phaseolus vulgaris L. (FEIJÃO). Revista Eletrônica de Educação e Ciência, 3(2), 01-06.

Dorota, S., Urszula, K., Renata, B. \& Agnieszka, G. (2013). Allelochemicals as Bioherbicides - Present and Perspectives, Herbicides Andrew J. Price and Jessica A. Kelton, IntechOpen. https://doi.org/10.5772/56185

Duke S. O. \& Powles, S. B. (2008). Glyphosate: A once-in-acentury herbicide. Pest Management Science, 64(4), 319325. https://doi.org/10.1002/ps.1518

El-Rokiek, K. G. \& Eid, R. A. (2009). Allelopathic effects of Eucalyptus citriodora on Amaryllis and associated grassy weed. Planta Daninha, 27(Special Issue), 887-899.

Florentine, S. K. \& Fox, J. E. D. (2003). Allelopathic effects of Eucalyptus victrix L. on eucalyptus species and grasses. Allelopathy, J 11, 77-83.

Gold, K. (2009). Manual of seed handling in genebanks by Kameswara Rao, N., Hanson, J., Ehsan Dulloo, M., Ghosh, K., Nowell, D. \& Larinde, M. xiv+147 pp. Rome, Italy: Bioversity international. The Journal of Agricultural Science, 147(1), 101-101. https://doi. org $/ 10.1017 / \mathrm{s} 0021859608008137$

Gomes, M. P., Bicalho, E. M., Smedbol, É., Cruz, F. V., Lucotte, M. \& Garcia, Q. S. (2017). Glyphosate can decrease germination of glyphosate-resistant soybeans. Journal of Agriculture and Food Chemestry, 65(11), 2279-2286. https://doi.org/10.1021/acs.jafc.6b05601

Heap, I. (2018). The International Survey of Herbicide Resistant Weeds. Available online: www.weedscience. com (accessed on 2707 2018).

Ismail, B. S., Chuah, T. S., Salmijah, S., Teng, Y. T. \& Schumacher, R. W. (2002). Germination and seedling emergence of glyphosate-resistant and susceptible biotypes of goosegrass (Eleusine indica [L.] gaertn.). Weed Biology and Management, 2(4), 177-185. https:// doi.org/10.1046/j.1445-6664.2002.00066.x

Jabran, K., Mahajan, G., Sardana, V. \& Chauhan, B. S. (2015). Allelopathy for weed control in agricultural systems. Crop Protection, 72, 57-65. https://doi.org/10.1016/j. cropro.2015.03.004

Morsi, M. M. \& Abdelmigid H. M. (2016). Allelopathic activity of Eucalyptus globulus leaf aqueous extract on Hordeum vulgare growth and cytogenetic behavior. Australian Journal of Crop Science, 2016 10(11), 15511556. https://doi.org/10.21475/ajcs.2016.10.11.pne122

Nishida, N., Tamotsu, S., Nagata, N., Saito, C. \& Sakai, A. (2005). Allelopathic effects of volatile monoterpenoids produced by Salvia leucophylla: inhibition of cell proliferation and DNA synthesis in the root apical meristem of Brassica campestris seedlings. Journal of Chemical Ecology, 31, 1187-1203. https://doi. org/10.1007/s10886-005-4256-y

Pawlowski, A., Kaltchuk-Santos, E., Zini, C. A., Caramao, E. B. \& Soares, G. L .G. (2012). Essential oils of Schinus terebinthifolius and S. molle (Anacardiaceae): mitodepressive and aneugenic inducers in onion and lettuce root meristems. S. African J. Botany, 80, 96-103. https://doi.org/10.1016/j.sajb.2012.03.003

Puig, C. G., Reigosa, M. J., Valentão, P., Andrade, P. B. \& Pedrol, N. (2018). Unravelling the bioherbicide potential of Eucalyptus globulus labill: Biochemistry and effects of its aqueous extract. PLoS One, 13(2): e0192872. https:// doi.org/10.1371/journal.pone.0192872

Radhakrishnan, R., Alqarawi, A. A. \& Abd_Allah, E. F. (2018). Bioherbicides: Current knowledge on weed control mechanism. Ecotoxicology and Environmental Safety, $\quad \mathbf{1 5 8}, \quad$ 131-138. https://doi.org/10.1016/j. ecoenv.2018.04.018

Rassaeifar, M., Hosseini, N., Haji, N., Zandi, P. \& Moradi, A. A. (2013). Allelopathic effect of Eucalyptus globulus essential oil on seed germination and seedling establishment of Amaranthus blitoides and Cyndon dactylon. Trakia Journal of Sciences, 1, 73-81.

SAS (2012). New Features in JMP ${ }^{\circledR}$ 10. Cary, NC: SAS Institute Inc.

Sebei, K., Sakouhi, F., Herchi, W., Khouja, M.L. \& Boukhchina, S. (2015). Chemical composition and antibacterial activities of seven Eucalyptus species essential oils leaves. Biology Research, 48(1), 1-5. https:// doi.org/10.1186/0717-6287-48-7

Tang, F., Chen, Y., Li, D. \& Huang, N. (2014). Allelopathic effects of volatiles from Eucalyptus grandis $\times$ E. urophylla leaves on seed germination and seedling growth of three 
kinds of plants. Medical Plant, 5(10), 33-39.

Vishwakarma, G. S. \& Mittal, S. (2014). Bioherbicidal potential of essential oil from leaves of Eucalyptus tereticornis against Echinochloa crus-galli L. Journal of Biopesticides, 7, 47-53.

Yamagushi, M. Q., Gusman, G. S. \& Vestena, S. (2011). Allelopathic effect of aqueous extracts of Eucalyptus globulus Labil. and of Casearia sylvestris sw. on crops. Semina: Ciências Agrárias, 32(4), 1361-1374. https://doi. org/10.5433/1679-0359.2011v32n4p1361
Yanniccari, M., Istilart, C., Giménez, D. O. \& Castro, A. M. (2012). Glyphosate resistance in perennial ryegrass (Lolium perenne L.) from Argentina. Crop Protection, 32, 12-16. https://doi.org/10.1016/j.cropro.2011.09.021

Zhang, J., An, M., Wu, H., Liu, D. L. \& Stanton, R. (2012) Chemical composition of essential oils of four eucalyptus species and their phytotoxicity on silverleaf nightshade (Solanum elaeagnifolium cav.) in Australia. Plant Growth Regulation, 68(2), 231-237. https://doi.org/10.1007/ s10725-012-9711-5 